\title{
Akademgorodok 2.0 as a Regional Scientific and Innovation Ecosystem: Problems of Formation and Management ${ }^{1}$
}

\author{
V. E. Seliverstov* \\ Center for Strategic Analysis and Planning, Institute of Economics and Industrial Engineering, Siberian Branch, \\ Russian Academy of Sciences, Novosibirsk, 630090 Russia \\ *e-mail: sel@ieie.nsc.ru \\ Received September 3, 2019; revised July 10, 2020; accepted July 21, 2020
}

\begin{abstract}
The article discusses the first steps towards implementing the Development Program for the Novosibirsk Scientific Center of the Siberian Branch of the Russian Academy of Sciences as a territory with a high concentration of research and development projects (megaproject Akademgorodok 2.0). The author analyzes the results of substantiating the prospects for developing the Novosibirsk Scientific Center in the area called the science polis zone of the Novosibirsk agglomeration. Approaches to constructing scenarios for developing this zone in the unity of socioeconomic, scientific, technological, infrastructural, and urban planning solutions are considered. The layouts of the future Akademgorodok 2.0 for the three considered scenarios are presented. The approaches to establishing the management system in the science polis zone are analyzed (including the one focusing on the Federal Law On innovative scientific and technological centers and on amendments to certain legislative acts of the Russian Federation). As an alternative management model, a proposal is formulated to organize the National Science and Technology Corporation for the Development of Siberia as a joint-stock company. It is not only to ensure the effective use of funds allocated for Akademgorodok 2.0 projects but also to address the issues of earning and reproducing the financial resources for these purposes. It is concluded that Akademgorodok 2.0 is among the successful experiences of setting up a regional scientific and innovation ecosystem in Russia. It is shown that integrating the regional strategic planning, territorial planning with modern urban planning solutions, and the planning and management of the scientific and technological development of the territory are fundamentally important for innovation ecosystem's management system.

Keywords: Novosibirsk scientific center, Siberian Branch, Russian Academy of Sciences, Novosibirsk State University, science polis zone, regional scientific and innovation ecosystem, strategy of scientific and technological development of the Russian Federation, Scientific and Educational Center, world-class centers of excellence, development scenarios, management system, National Science and Technology Corporation for the Development of Siberia
\end{abstract}

DOI: $10.1134 /$ S2079970520040103

\section{AKADEMGORODOK 2.0 MEGAPROJECT: GETTING STARTED}

Three divergent trends significantly determined the spatial development of the Russian Federation in the post-Soviet period. First, the centripetal development with the further concentration of economic activity in the capital's agglomerations of the European part of the country (primarily in Moscow and St. Petersburg). Second, the further consolidation of the raw-materials' orientation characterizing the development of Russia's East. Third, the country's image-building projects implemented in several cities and involving colossal budgetary and extrabudgetary costs. Together they have formed the state's spatial structure as rather archaic and incapable of meeting the scientific, technological, and humanitarian challenges of the 21st

\footnotetext{
${ }^{1}$ The article was updated by the author in 2020 for publication in Regional Research of Russia.
}

century. The fate of strategic initiatives aimed at creating new economic growth points in Russian regions, which do not fit into these three vectors of Russia's spatial development, is all the more interesting in this context.

One of the most fascinating projects for Siberia's nonprimary development is the strategic initiative aimed at establishing a world-class National Center for the Integration of Science, Education, and HighTech Business of World Importance in Novosibirsk oblast (Akademgorodok 2.0). ${ }^{2}$ In the article [18], we described the emergence and start of the development

\footnotetext{
${ }^{2}$ Initially, this strategic initiative was called the Siberian science polis zone. The official documents use the term Plan (Program) for the development of the Novosibirsk Research Center as a territory with a high concentration of research and development projects. For brevity, we will use the term Akademgorodok 2.0 megaproject or simply Akademgorodok 2.0. The territory where this megaproject is being implemented is called the science polis zone.
} 
of this strategic initiative, as well as its basic principles and directions of implementation. It should be recalled that Akademgorodok 2.0 is an institutionalized integration of the following organizations:

- Novosibirsk Scientific Center (NSC) of the Siberian Branch, Russian Academy of Sciences (SB RAS) and its nearly 30 research institutes;

- Novosibirsk National Research State University (NSU);

- Technopark of Novosibirsk Akademgorodok (Academpark);

- Naukograd (science-oriented urban settlement) Koltsovo with its innovative biotechnology companies and Biotechnopark;

- Meshalkin National Medical Research Center;

- Medical and agricultural institutes formerly included in the sectoral academies of sciences;

- High-tech companies and innovative infrastructure facilities operating in this area.

From the standpoint of the theory and practice of regional economics, the Akademgorodok 2.0 megaproject is of particular interest as a model example of combining regional strategic planning and management, strategic planning of scientific and technological development and territorial planning. The latter aims to optimize the spatial development of the model area based on urban and infrastructural solutions. From the standpoint of institutional economics, this project is relevant as an attempt to overcome the defects of the existing Russian institutions, norms, and rules on the way to establishing an effective regional scientific and innovative system. From the standpoint of innovation economics, it is interesting as a model example of launching a regional scientific and innovative conveyor. This conveyor drives innovation through all stages of its implementation cycle and takes the opportunities for commercializing the results of scientific research in breakthrough technologies.

Notwithstanding the effectiveness of the first stage of establishing Akademgorodok 2.0, three points are very important:

- awareness of the scientific and regional elites of the fact that progress in the development of the NSC is possible only based on a significant strengthening of the integrational interactions of the Academy's institutes, higher education, and industrial partners, as well as by enhancing cooperative ties between the basic territories concentrated around the Novosibirsk Akademgorodok;

- first signs of increasing attention paid by the federal center to the problems and prospects of the new development stage of the NSC SB RAS;

- carrying out a scientific-expert inventory of the crucial developments attained by the institutes of the NSC SB RAS, resulting in several dozen informed proposals for the development of scientific infrastruc- ture and innovative projects in this area, many of which have an integrative character.

In general, the development program of the NSC SB RAS as a territory with a high concentration of research and development projects (Akademgorodok 2.0 megaproject) is very complex from the standpoint of managing its implementation. It is an example of a large multiagent project with numerous participants [5]. In all likelihood, during its implementation, it will not be possible to avoid mistakes and incorrect steps. It will be connected to the difficulties of reaching a general consensus among its participants and balancing their interests. Now, this program is at the first (initial, preparatory) stage when quality system solutions, design, and strategic development are especially important.

Thus, the research results on drawing up an advanced development zone, the science polis zone in the Novosibirsk agglomeration, ${ }^{3}$ are of great interest. In 2019, on the instructions of the Ministry of Construction of Novosibirsk oblast, this work was carried out by LLC Concept-Project assisted by the staff members of the Institute of Economics and Industrial Engineering (IEIE) SB RAS. The author of the article headed the development of the socioeconomic and management blocks. ${ }^{4}$ The purpose of this work was to substantiate the future spatial framework of Akademgorodok 2.0 in a unified strategic direction for developing this territory and specific projects for the development of scientific, innovation, transport, social, engineering infrastructure, and urban planning solutions.

Let us briefly mention some of the results of this development obtained directly by the author.

Thus, analysis of the development potential available in the supporting territories of the science polis zone shows that each of them and each of their scientific and innovative agents-research institutes of the NSC SB RAS, NSU, and high-tech business-have significant development potential. However, in the past, it was realized mainly based on them pursuing their own interests. The only exceptions were the historically close interactions between NSU and specialized research institutes of the Academy. Their integrational ties were limited by financial, institutional, and interdepartmental barriers. This situation significantly undermined the possible synergistic effect of their

\footnotetext{
${ }^{3}$ The advanced development zone The Science Polis Zone of the Novosibirsk Agglomeration is the spatial area of the implementation of the development program of the NSC as a territory with a high concentration of research and development projects (Akademgorodok 2.0), including the Sovetsky and Pervomaysky districts of Novosibirsk, urban-type settlements naukograd Koltsovo and Krasnoobsk, the city of Berdsk, the territory of the Baryshevskii and Michurinskii local councils of Novosibirsky municipal district in Novosibirsk oblast.

${ }^{4}$ The participants of the work were Yu.S. Ershov, Cand. Sci. (Economics) G.V. Zhdan, Dr. Sci. (Economics) V.D. Markova, and Cand. Sci. (Economics) L.V. Melnikova.
} 
interaction, which, in turn, prevented the full-scale realization of the economic, scientific, and innovative potential of this territory.

It was also concluded that the necessary critical mass had been formed for a new integration stage of the supporting territories in the science polis zone and its main economic, scientific, and innovation agents. It was facilitated both by the creation of the necessary innovative infrastructure (technoparks, innovation clusters, competence centers, prototyping centers, collective use centers, and business incubators) and development institutions in this zone, as well as by the realization that focusing on individual survival is fraught with serious negative consequences both for Siberian science, higher education, and for innovative business. This was supported by the presence of scientific and innovative projects of national importance.

Another important block of this work consisted of an attempt to assess various scenarios for the future development of Akademgorodok 2.0. Proceeding from the existing trends, we have formulated prerequisites, hypotheses, and demographic forecast, ${ }^{5}$ several possible scenarios for developing the science polis zone over the period up to 2035. Based on the scenarios, the layout of the future Akademgorodok 2.0 was predicted under various combinations of external and internal conditions and factors of its development. At the same time, it was important to coordinate the prospective estimates of the economic, scientific, technological, and educational potential of the science polis zone with an assessment of the development of the social, transport, and engineering infrastructure, as well as with the management system and institutional conditions necessary for the realization of these potentials.

In constructing scenarios for the development of the science polis zone, it was necessary to take into account not only the scientific, innovative, and infrastructural projects expected to be implemented in this territory but also the external conditions, challenges, threats, and restrictions (in the global and national contexts), as well as the options for the prospective positioning of Novosibirsk oblast, the city of Novosibirsk, as well as the entire South Siberian macroregion in the system of the national economy and international economic relations.

We considered four scenarios of the development of the science polis zone:

- the base scenario of the first development stage up to 2025 ;

- inertial development scenario for the period up to 2035 ;

- innovative development scenario for the period up to 2035 ;

- active innovative development scenario for the period up to 2035 .

\footnotetext{
${ }^{5}$ Developed by Yu.S. Ershov at the IEIE SB RAS.
}

Their difference lay in the scope of the external influences (in particular, the possibility of state support for the main projects and strategic initiatives of the Akademgorodok 2.0 megaproject, the level of compliance with the Presidential Executive Order signed on May 7, 20186 ), in the number and composition of projects being implemented, ${ }^{7}$ and in the specifics of the institutional environment and options for organizing the management system in the science polis zone. ${ }^{8}$ Let us dwell only on the main characteristics of the layout of the future Akademgorodok 2.0 in these scenarios.

\section{LAYOUT OF THE FUTURE AKADEMGORODOK 2.0 IN THE INERTIAL SCENARIO}

The unfolding of this scenario will lead to the inertial development of the NSC SB RAS with the implementation of single separate projects for the development of scientific, educational, innovation infrastructures; high-tech production projects from regional technology leaders; and investment projects approved by the government of Novosibirsk oblast for the development of industry and other segments of the economy. The implementation of the inertial scenario will reduce the research and human potential of the NSC SB RAS. In the context of adopting the conservative version of the Law on Science and insufficient financial support for RAS institutes, the outflow of scientific personnel from the NSC SB RAS institutes will continue, and the inflow of young people into them will be minimal. Integrational ties between science, education, and high-tech business in the science polis zone, as well as in its supporting territories, will not be implemented sufficiently. Nevertheless, the NSC SB RAS status as a leading regional research and innovation center in Russia will generally be retained, although there will be risks of losing leadership in several $R \& D$ areas.

\footnotetext{
${ }^{6}$ Presidential Executive Order signed on May 7, 2018, On National Goals and Strategic Objectives of the Russian Federation through to 2024. http://en.kremlin.ru/events/president/ news/57425. Accessed April 21, 2020.

7 Three large projects (Center for Collective Use "Siberian Ring Photon Source" in Koltsovo, Center for Genetic Technologies, and part of NSU's infrastructure development project) in the inertial scenario; a complete list of 45 projects in the active and innovative scenarios.

${ }^{8}$ From the conservative version of the use of Federal Law no. 216-FZ On Innovative Scientific and Technological Centers and on Amendments to Certain Legislative Acts of the Russian Federation in the inertial scenario before the publication of the Federal Law On the Novosibirsk Scientific Center in the active innovative scenario. This law can provide the science polis zone with a system of powers, benefits, and preferences similar to those provided to the Skolkovo Innovation Center.
} 


\section{LAYOUT OF THE FUTURE \\ AKADEMGORODOK 2.0 \\ IN THE INNOVATIVE SCENARIO}

The implementation is ensured for the development of the NSC (Akademgorodok 2.0) in the format of transforming it into a leading Russian center for science and innovation. The best-prepared projects for the development of scientific, educational, and innovative infrastructures, as well as projects for high-tech industries, are implemented, including those proposed by Russian technological leaders. The staffing and financial support of the NSC SB RAS institutes is stabilized. The integrational interactions between the supporting territories of the science polis zone are enhanced. In the 5-100 Federal Program (maximum strengthening of the competitive position of a group of leading Russian universities in the global market of educational services and research programs), NSU firmly consolidates its position among the top three universities in Russia and the world's 100 best universities. The Scientific and Educational Center (SEC) set up at NSU becomes a model example of the integration between science and the system of training highly qualified personnel. The SEC NSU Competence Centers reach world standards. In the science polis zone, an advanced system of integration between science, education, and high-tech business in Russia, as well as one of the best life support systems in the country, is formed.

\section{LAYOUT OF THE FUTURE AKADEMGORODOK 2.0 IN THE ACTIVE INNOVATION SCENARIO}

Intensive development of the science polis zone will be carried out as a center for integration between science, education, and high-tech business of global significance based on the implementation of the entire list of announced projects and a new package of projects for the development of scientific, educational, and innovative infrastructures, as well as projects of high-tech industries, including those from the world's technology leaders. The special status of the science polis zone and favorable and comfortable conditions for scientific research and conducting science-intensive business will significantly strengthen the NSC SB RAS institutes and incorporate them into the regional innovation and production system. It will also create hundreds of new small and medium-sized innovative companies and several large high-tech enterprises. The model of the Siberian scientific and innovative conveyor will be implemented, the main elements of which can also be introduced in other regions of Russia. A life support system that meets international standards will be formed in the science polis zone. The creation of a new scientific and innovation ecosystem of Akademgorodok 2.0 will be completed based on the integration of science, education, and high-tech business, as well as the comprehensive scientific, innovative, social, and transport infrastructure created for this.

System development proposals for the NSC SB RAS as a territory with a high concentration of research and development centers were reflected in a series of reports, presentations, and exhibition stands of Novosibirsk oblast at the largest forums and exhibitions held in Russia (St. Petersburg and Sochi economic forums, the international industrial exhibition Innoprom in Yekaterinburg, international forums of technological development, Technoprom, in Novosibirsk). Thus, a critical mass of such systemic proposals and justifications is being accumulated, and the position of the scientific and expert communities in relation to certain areas of implementing this strategic initiative is important. From this point of view, we will consider the possible approaches to the management system for Akademgorodok 2.0.

\section{POSSIBLE GOVERNANCE MODELS AND LEGAL FRAMEWORK OF AKADEMGORODOK 2.0}

The success of the Development Program for the NSC SB RAS as an area with a high concentration of $\mathrm{R} \& \mathrm{D}$ projects will be determined by the presence and interaction of the following four components:

- a high level of scientific and innovative potential of science, higher education, and high-tech business on the NSC territory;

-a set of innovative projects in the breakthrough areas of the scientific and technological development based on the existing potential and key competencies attained by the participants of the regional scientific and innovation system;

- the governance system in the science polis zone and the special status of this zone, which creates favorable conditions for effective scientific activity and innovative business and realizes the synergistic effect of the interaction of science, education, and high-tech business;

- significant allocations of the state and private investors for the development of Akademgorodok 2.0.

The Russian experience in establishing regional innovation systems shows that the absence of any one of these four components significantly undermines the integral results of their development. For example, the colossal state expenditures on setting up the Skolkovo Innovation Center in Moscow and the creation of a special regulatory regime for innovation there have not brought about the expected results since the development of this center was not based on the strong scientific and high-tech potential of its participants. The center was established in the greenfield paradigm (development from scratch, without an existing success story, strong teams with extensive 
experience in scientific development and implementation, etc.). ${ }^{9}$

The NSC SB RAS development program has the first two components: the potential for development and interaction among the NSC SB RAS, NSU, and innovative business, as well as a set of promising development projects based on the key competencies of the Academy's institutes, NSU, Novosibirsk State Technical University, high-tech companies, and innovative infrastructure [7]. The other two components (the governance system and the special status of the territory, as well as the financial and material resources allocated for the development of the NSC SB RAS) are the prerogative of the federal center and depend both on the financial capabilities of the state budget and on the mechanisms for implementing the national scientific and technical policy and The Strategy of Scientific and Technological Development of the Russian Federation. ${ }^{10}$ Nevertheless, when making decisions on the forms of governance organization in the science polis zone, the positions of the regional scientific and expert communities, the business community, and the local government bodies should be taken into account.

The governance system in the science polis zone should include three independent (albeit, interrelated) blocks:

(1) governance of the territory with a high concentration of research, development, innovation infrastructure, and high-tech production;

(2) management of strategic scientific and technological implementation directions of the Akademgorodok 2.0 project;

(3) managing the processes of initiation, selection, and implementation of specific scientific and innovative projects.

Accordingly, the issues of obtaining and spending federal resources for the implementation of the Akademgorodok 2.0 project, the formation of a particular regulatory and legal environment for the comfortable conduct of scientific activities and business, and the attraction of institutional investors should be considered not in general but in the format that they are targeted to specific MegaScience projects, to the NSU development program, to the transport and infrastructure development program of the science polis zone, etc.

Foreign and Russian models of managing regional scientific and innovation systems use various mechanisms to regulate, stimulate, and control these pro-

\footnotetext{
${ }^{9} \mathrm{RBC}$ investigation: what happened to Skolkovo. RBC, March 23, 2015. https://www.rbc.ru/business/23/03/2015/ 5509710a9a7947327e5f3a18. Accessed February 12, 2020. V. Gromovsky. What happened to Skolkovo? // Expert, March 24, 2015.

${ }^{10}$ The Strategy of Scientific and Technological Development of the Russian Federation, http://www.consultant.ru/document/cons_doc_LAW_207967/.Accessed May 02, 2020.
}

cesses $[2,9-13,15]$. The studies emphasize a unique role played by leading universities in forming such sytems and their relationship with large corporations' orders $[8,16,17]$. Foreign publications note, on the one hand, the great influence of the supranational (e.g., within the EU) and national innovation management policy on how regional innovation systems and systems for their management are being shaped. On the other, it is underlined that there is no unified regional innovation policy, and each region should develop its policy in this area, taking into account its own characteristics and competitive opportunities [14].

The concept for the development of the NSC (of Novosibirsk Akademgorodok) as a territory with a high concentration of research and development, prepared in September 2018 by the Ministry of Science and Higher Education of the Russian Federation together with the SB RAS and the government of Novosibirsk oblast, considers three possible models for managing the NSC development:

- conferring on the NSC the status per Federal Law no. 473-FZ of December 29, 2014 On the territories of advanced socioeconomic development in the Russian Federation; ${ }^{11}$

- conferring on the NSC the status of an innovative scientific and technological center (ISTC) per Federal Law no. 216-FZ of July 29, 2017 On innovative scientific and technological centers and on amendments to certain legislative acts of the Russian Federation; ${ }^{12}$

- adopting the special Federal Law On the Novosibirsk Scientific Center integrating the advantages of the federal laws given above (by analogy with Federal Law no. 244-FZ of September 28, 2010 On the Skolkovo Innovation Center ${ }^{13}$ ).

It was concluded that the mechanism for creating the ISTC was aimed in general at developing research, development, and commercialization of their results. However, if this management model is applied, significant changes will need to be included in the Federal Law no. 216-FZ, which will take into account the specifics of the creation and operation of the NSC SB RAS. Thus, it was noted that to increase the investment attractiveness of the R\&D sphere, as well as commercialize the results of the ISTC's activities, it

\footnotetext{
${ }^{11}$ Federal Law no. 473-FZ of December 29, 2014 On the Territories of Advanced Social and Economic Development in the Russian Federation. http://www.consultant.ru/document/ cons_doc_LAW_172962/. Accessed June 22, 2020.

${ }^{12}$ Federal Law no. 216-FZ of July 29, 2017 (as amended on July 26, 2019) On Innovative Scientific and Technological Centers and on Amendments to Certain Legislative Acts of the Russian Federation. http://static.kremlin.ru/media/acts/files/ 0001201707300035.pdf. Accessed June 18, 2020.

${ }^{13}$ Federal Law no. 244-FZ of September 28, 2010 On the Skolkovo Innovation Center. http://www.consultant.ru/document/cons_doc_LAW_105168/. Accessed July 02, 2020.
} 
will be necessary to amend this law, providing for an institute of residents of innovative scientific and technological centers.

It is important that in the NSC's development concept, the potential of the third management model is properly appreciated. It is noted that, taking into account the need to create the standard model for the development of individual territories (regions) with a high concentration of research and development, one of the promising options would be the publication of the Federal Law On the Novosibirsk Scientific Center by analogy with the Federal Law On the Skolkovo Innovation Center. This approach will provide the necessary conditions not only for R\&D but also attracting investment in production. At the same time, it is noted that implementing this approach requires allowance for the time constraints associated with creating Akademgorodok 2.0 and the lengthy procedure for developing and adopting a federal law.

Generally, in drawing up strategic directions for the development of Akademgorodok 2, the Ministry of Science and Higher Education of the Russian Federation, the government of Novosibirsk oblast, and the SB RAS Presidium are inclined to favor the format of implementing Federal Law no. 216-FZ. Further, we present our vision of possible forms for organizing a governance system in the science polis zone under this model adapted to this zone's local specifics and development potential.

\section{SETTING UP AN INNOVATIVE SCIENTIFIC AND TECHNOLOGICAL CENTER AT THE NSC SB RAS}

In principle, implementing Federal Law no. 216FZ and establishing a governance system corresponding to it should not involve great difficulties only if the law is enforced on a relatively compact territory and with a small number of participants in the regional scientific and technological center. Among them, a scientific and innovative leader who can take on the functions of initiating a project for its creation stands out. The complexity of implementing this law in the Novosibirsk science polis zone is determined by the large number (several dozen) of scientific and innovation agents who can become members of the new scientific and technological center. Different forms of ownership of land and property held by its participants-federal, regional, and local-are intertwined here, creating many problems.

In the Russian Federation, there are still no examples of the enforcement of the Federal Law no. 216-FZ and only two innovative scientific and technological centers are on the verge of being launched based on it: within the NSC SB RAS Development Program and in the newly created Scientific and Technological Valley of the Lomonosov Moscow State University (ISTC Vorobyovy Gory). The initiators of setting up these centers have the right to prepare proposals for their creation, taking into account the local specifics. Let us consider how to do this in the Novosibirsk Akademgorodok and combine the management system at the Novosibirsk Innovation Science and Technology Center (NISTC) with the management system for scientific and innovative development at the NSC as a whole.

The SB RAS and NSU should become the coorganizers and initiators of creating the NISTC. The main management structures formed in accordance with the Federal Law no. 216-FZ will be the NISTC Foundation and the NISTC Management Company, in which representatives of these organizations should play a key role. The institutes of the Academy, Academpark, and other innovative companies located in the science polis zone can be given a participant's status in setting up this center.

Since in the future, scientific and innovative activities in the science polis zone will be carried out based on the principles of clustering, it is advisable to form six scientific and technological clusters ${ }^{14}$ here with the appointment of the head organization and establishment of an intracluster system for managing the interaction of cluster members and integrating them into the overall management system in this zone.

The generated management model in the science polis zone should include a system of interaction with the objects and subjects of scientific activity and innovation infrastructure created here, as well as with the management structures of Novosibirsk oblast and the city of Novosibirsk. Within the latter's framework, new or existing bodies for managing scientific, technological, and innovative development should be created or strengthened. Thus, at the Ministry of Science and Innovation Policy of Novosibirsk oblast, it is advisable to create an Agency for Innovative Development, whose functions should be largely focused on implementing the Akademgorodok 2.0 project.

As the main initiators and subjects of scientific and innovative activities in the science polis zone, the SB RAS and NSU work out and establish a unified R\&D management system (which should organically include the NISTC). This system's elements are joint scientific boards (JSBs) in the branches of sciences represented at the SB RAS and world-class centers of excellence within the SEC at NSU. However, it is necessary to expand the composition of the JSBs to include representatives of industrial partners that coincide with the board's scientific profile. To work out a unified scientific and technical policy for carrying out R\&D in the science polis zone, an Interdepart-

\footnotetext{
${ }^{14}$ Nuclear technology clusters (including nuclear medicine); information technologies; photonics and microelectronics; genetic technologies, biopharmaceuticals and biotechnologies; new materials (including nanostructured materials and powder technologies); catalyst cluster.
} 


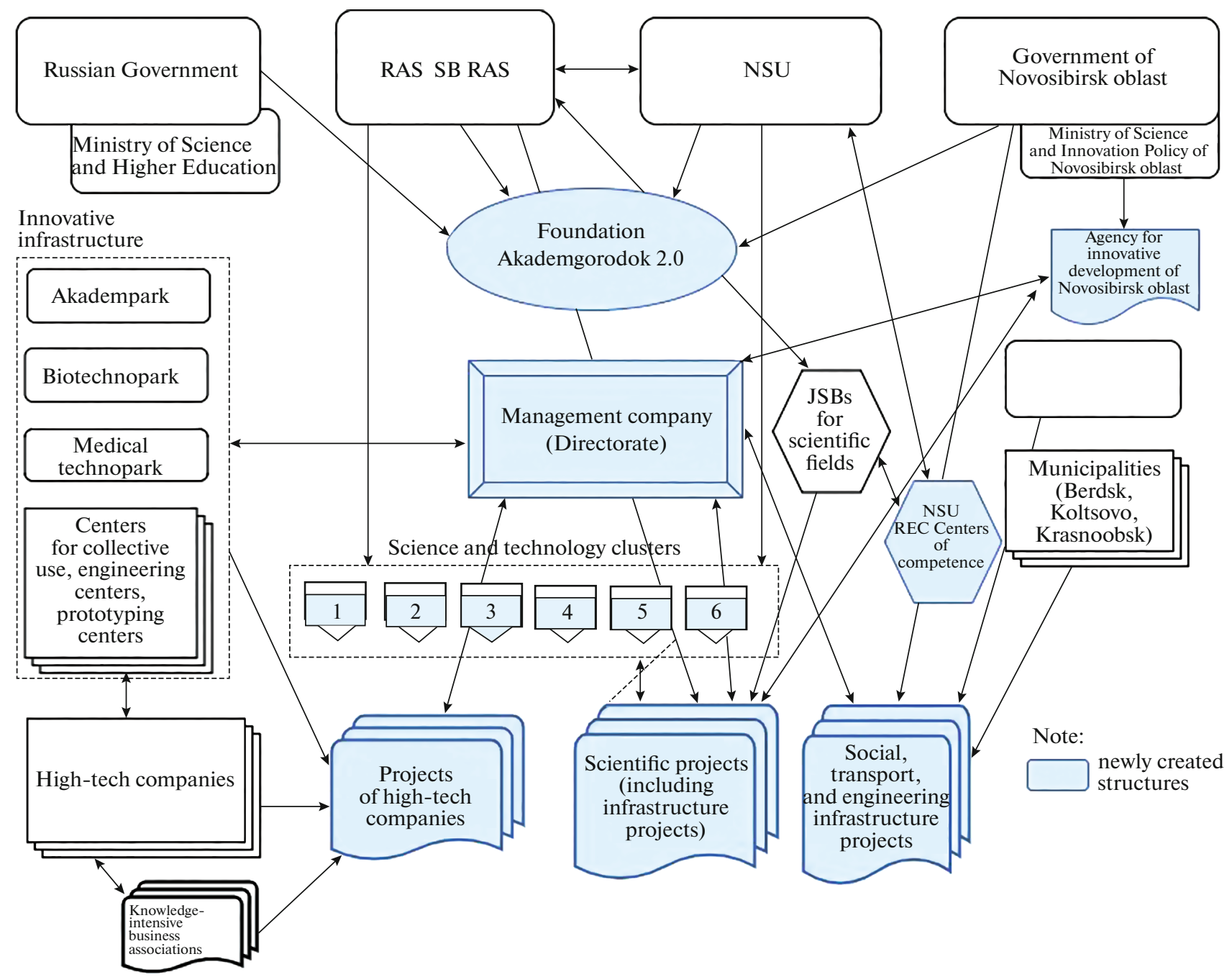

Fig. 1. Novosibirsk Innovation Science and Technology Center in the management scheme in the science polis zone.

mental Scientific Coordination Council should be set up.

Industrial partners and innovative companies of the science polis zone are embedded in the management system through their representatives in the relevant managing bodies. In turn, the management system actively uses the existing associative forms of integration and interaction of innovative companies (the SibAcademSoft and Biopharm associations, nonprofit partnership SibBioMed, etc.).

The general scheme of the management model in the science polis zone, which incorporates NISTC, is shown in the Figure 1. Its peculiarity is that it is constructed not as the model of territorial management (areas of the science polis zone) but as the model for managing developments, projects, and innovations, implemented based on the design-functional principle. The main structural object of management here is a scientific and technological, innovative, or infrastructural project. Therefore, the entire management system in the science polis zone should be maximally aimed at its implementation at all stages: initiation, justification, approval, support and maintenance, and control over the results of the implementation. It is assumed that a significant number of such projects should be implemented based on the NISTC and its interaction with scientific institutions, NSU, and innovative companies. Another feature of this management model is that it uses the existing organizational and management structures, and soft associative forms of coordination and regulation.

It is assumed that the management of scientific and technological projects and projects for the formation of scientific and innovative infrastructure should be carried out according to a centralized and decentralized scheme. Within each of the six scientific and technological clusters, a project office should be created, the functions of which will include initiating specific projects according to the cluster's profile, developing project documentation, preparing business 
plans and financial models, and assessing risk and market conditions.

The project office must also be set up within the structure of the NISTC Management Company (Directorate). It addresses the issues of evaluating and supporting projects received from the project offices of each cluster, and it assesses the possibilities of obtaining state support for a particular project through programs and funds of the federal and regional levels, as well as investment programs of state corporations and natural monopolies, etc. This project office should also consider, evaluate, and support projects received from other participants in the regional science and innovative system (i.e., those that are submitted outside the cluster's initiatives).

Thus, each functional vector of this management system must fulfill its tasks in the sphere of enhancing scientific and innovative activities, developing hightech production, training highly qualified personnel, and developing an innovative infrastructure.

The issues associated with the social, transport and engineering infrastructure should be addressed within the existing state and municipal government system in Novosibirsk oblast and involve federal resources. Since the development of such an infrastructure is clearly intermunicipal in nature, in order to regulate these processes, on July 1, 2019, an agreement was signed on interaction and cooperation in the creation and development of the NSC in the advanced development zone, the science polis zone of the Novosibirsk agglomeration of Novosibirsk oblast. This agreement was signed by the administrations of Novosibirsk oblast, city of Novosibirsk, city of Berdsk, naukograd Koltsovo, urban-type settlement Krasnoobsk, and other territories involved in the implementation of this strategic initiative.

This management model for the science polis zone provides that all the main participants in the regional science and innovative system (the institutes of the SB RAS, NSU, innovative infrastructure facilities, hightech companies) retain their status. However, at the same time, new coordinating structures are set up to strengthen their integrational interactions in a mild form.

Federal Law no. 216-FZ does not directly provide for special tax regimes and tax incentives or the possibility of establishing them for participants in innovative scientific and technological centers. However, on January 1, 2019, special ISTC taxation conditions came into force, established by a special federal law. This law stipulates benefits for the ISTC funds and management companies, and for participants in projects implemented within the center. Thus, the ISTC funds and management companies are completely exempt from paying corporate property tax, and the projects' participants are exempt from paying this tax for 10 years. In general, the incentives granted to innovative scientific and technological centers are similar to those provided to the Skolkovo Innovation Center participants. ${ }^{15}$

Thus, the adoption of the Federal Law no. 373-FZ formally reconciles the two management models of Akademgorodok 2.0 mentioned in the Development Concept of the NSC (Novosibirsk Akademgorodok) as a territory with a high concentration of research and development (i.e., based on the use of the Federal Law no. 216-FZ and based on the adoption of the special Law On the Novosibirsk Scientific Center similar to the Law On the Skolkovo Innovation Center).

It is not accidental that we are using the expression formally reconciles. The point is (and it stands as the central thesis in our analysis) that the fact of the NISTC emerging does not create a management model for the NSC as a territory with a high concentration of research and development (Akademgorodok 2.0 ), on which great hopes were pinned. By the estimates made by the Ministry of Justice and the Ministry of Construction of Novosibirsk oblast, the NISTC's territory should not exceed 15-50 ha (although the boundaries of the NSC SB RAS cover land plots with the total area of 12100 hectares). In other words, new preferential conditions for conducting scientific and innovative activities (tax incentives and others) will operate within the boundaries of the territory that makes up several percent of the entire area of the NSC SB RAS.

Formally, NISTC is a new "large technopark" with preferential conditions for implementing scientific and innovative activities (which, by the way, are absent in the successfully operating Academpark). The NISTC, of course, can become the essential element for the new stage of scientific and technological development of Akademgorodok 2.0, and it can be used for development projects of the NSC, including some (but not all) projects of Akademgorodok 2.0 for the formation of new objects of innovative infrastructure.

However, the NISTC does not solve all the problems of creating a National Center for the Integration of Science, Education and High-Tech Business, formulated in the Concept for the Development of the NSC as a territory with a high concentration of research and development. Its creation will not affect plans to modernize the social, transport, and engineering infrastructure within the science polis zone (per the Federal Law no. 216-FZ, an innovative scientific and technological center can create social infrastructure facilities only on its territory). Indeed, the NISTC management system cannot be the base of the new management model of Akademgorodok 2.0 since

\footnotetext{
${ }^{15}$ Federal Law no. 373-FZ of October 10, 2018 On Amendments to Parts One and Two of the Tax Code of the Russian Federation in Connection with the Adoption of the Federal Law On Innovative Scientific and Technological Centers and on Amendments to Certain Legislative Acts of the Russian Federation. http://www.consultant.ru/document/cons_doc_LAW_310010/. Accessed June 09, 2020.
} 
the overwhelming majority of its scientific and innovative agents (and territories) will live according to the traditional model. Only a small area of the science polis zone will be subject to the new preferences and the new regulatory regime. Thus, with the establishment of the NISTC, the issue of creating an effective management system for the scientific, technological, social, and urban development of Akademgorodok 2.0 remains unresolved.

\section{DESIGN AND TERRITORIAL MODEL FOR THE ORGANIZATION OF GOVERNANCE IN THE SCIENCE POLIS ZONE}

By default, it is assumed that the NSC's development program will be implemented as a departmental program of the Ministry of Science and Higher Education of the Russian Federation. Like any other bureaucratic structure, this federal ministry will implement the program within its own targets, departmental rules, and restrictions. By doing that, it will impede the introduction of management innovations in the science polis zone. The ministry will act within the existing scope of allocated authority and financial resources to support the entire system of the RAS and higher education. Estimates show that such resources are clearly insufficient for this program; therefore, we should not expect the Ministry of Science and Higher Education of Russia to provide exclusive preferences specifically to the NSC SB RAS over other research centers and universities in the country.

Besides, it should be borne in mind that at least seven organizations and departments will participate in the development of the science polis zone on the territory of Akademgorodok, urban-type settlement Krasnoobsk, naukograd Koltsovo, regional authorities, municipalities, the SB RAS, Ministry of Education and Science of Russia, Ministry of Health of Russia, Ministry of Agriculture of Russia, and Federal Service for Supervision of Consumer Rights' Protection and Human Welfare.

Considering the legal forms for the territorial organization of the spatial relations in the NSC, it should be kept in mind that, unlike other Russian and foreign science poleis and regional scientific and innovative systems, here we are dealing with an enclave urban agglomeration formation that unites several administrative-territorial units of different status. Such a structure significantly complicates the implementation of joint intermunicipal projects and programs (primarily infrastructural). Implied expenditures do not yet fit into the norms and rules stipulated in the Budget Code of the Russian Federation.

Thus, an effective management model of Akademgorodok 2.0 as a territory with a high concentration of research and development requires one indispensable condition, namely, an interdepartmental approach, enshrined in the special status of this entire territory, and not a separate part of it (as in the case of the NISTC). As noted above, this would be possible with the adoption of the Federal Law On the Novosibirsk Scientific Center, which would provide the science polis zone with a system of powers, benefits, and preferences similar to those provided to the Skolkovo Innovation Center, but taking into account the local specifics and development challenges and interaction of the main actors of the Novosibirsk regional scientific and innovative system. Another option is to give this strategic initiative the status of a national project implemented through the Council for Strategic Development and Priority Projects under the President of the Russian Federation. This national project should be implemented under the patronage of senior state officials, which will make it possible to move away from a narrow departmental approach. The third, most radical option, is establishing the National Science and Technology Corporation (company) for the Development of Siberia, which will oversee all the regional scientific and innovation centers in the macroregion. However, its core should be the NSC, Akademgorodok 2.0.

All three indicated options will require additional justification and appropriate amendments to the Russian legislation. However, most likely, each option will provide for establishing in the management system of the science polis zone a special fund, a directorate, a supervisory board, a scientific advisory board, a project office to support scientific and innovative projects, and a department (committee) for attracting investment.

We are rather skeptical about the scale of the state's presence in the Russian economy, but we believe that in the case of Akademgorodok 2.0, such a presence is necessary. Despite the innovative rhetoric of the heads of state corporations and vertically integrated companies, it should be admitted that Russian business has neither the means nor the desire to participate in the rise of Russian science and the launch of regional scientific and technological conveyors. Hence the question: Which configuration should be formalized for the state's participation in the development of Akademgorodok 2.0? The simple use of the Federal Law no. 216-FZ, as shown above, is unlikely to give the expected results. Setting up the State Corporation for Scientific and Technological Development of Siberia on Rostec and other state corporations' principles, on the one hand, is unlikely, and on the other hand, it is not particularly advisable. As the experts have shown [1], state corporations ${ }^{16}$ in their current form are a rudiment of the Soviet era and unlikely to stand the test of time.

However, the issue of the role, functions, and capabilities of the state in relation to its participation in the implementation of the Akademgorodok 2.0 megaproject gets a completely different coloring if we state the following hypothesis: the management model in the 
science polis zone should not only ensure the initiation of scientific and innovative projects and the rational control of funds allocated for their implementation but also to solve the problem of earning and replenishing financial resources for these purposes.

In this case, the creation of a National Science and Technology Corporation (company) for the Development of Siberia (not to be confused with a state corporation) in the form of a joint-stock company with the state holding the majority of shares will make it possible to solve both the main problems of managing Akademgorodok 2.0 and the task of asset replenishment for the scientific and technological development of Siberia. It is possible, among other things, by the public listing of the corporation's shares. Such a corporation will be vitally interested in all research, innovative, and infrastructure projects in the Akademgorodok 2.0 megaproject to succeed, since this will ultimately increase its financial assets. The shareholders of this national corporation (company), in addition to the state represented by the federal government and the governments of Siberian and other regions, may be large Russian corporations and companies ready to participate on an equal footing in such a large-scale venture capital project, as well as large high-tech foreign businesses. ${ }^{17}$

In the latter case, it should be taken into account that since one of the most important tasks of the development program of the NSC as a territory with a high concentration of research and development is to increase the importance of the NSC in the world's science and technology space, it is necessary to more actively involve the space itself in this megaproject. Suppose MegaScience facilities are created here with the possibility of foreign researchers working there on orders from national governments or corporations. Why not, say, involve such a structure as BRICS represented by the BRICS New Development Bank in this activity (this bank is designed to promote the development of large infrastructure projects)? Atten-

\footnotetext{
${ }^{16} \mathrm{~A}$ state corporation is a form of business ownership of nonprofit organizations in Russia with no membership. It is established based on the federal law on its creation and property contribution to implement social, managerial, or other socially useful functions. A feature of state corporation status is significantly less control by state bodies and weak requirements for disclosing information about their activities. As a rule, public corporations are not subject to bankruptcy. https://ru.wikipedia.org/wiki/\%D0\%93\%D0\%BE\%D1\%81\%D1\%83\%D0\%B4 $\% \mathrm{D} 0 \% \mathrm{~B} 0 \% \mathrm{D} 1 \% 80 \% \mathrm{D} 1 \% 81 \% \mathrm{D} 1 \% 82 \% \mathrm{D} 0 \% \mathrm{~B} 2 \% \mathrm{D} 0 \% \mathrm{~B} 5 \% \mathrm{D}$ $0 \% \mathrm{BD} \% \mathrm{D} 0 \% \mathrm{BD} \% \mathrm{D} 0 \% \mathrm{~B} 0 \% \mathrm{D} 1 \% 8 \mathrm{~F} \% \mathrm{D} 0 \% \mathrm{BA} \% \mathrm{D} 0 \% \mathrm{BE} \%$ D1\%80\%D0\%BF\%D0\%BE\%D1\%80\%D0\%B0\%D1\%86\%D0 $\%$ B8\%D1\%8F. Accessed June 09, 2020.

${ }^{17}$ One should not discount the possibility of using people's funds in this corporation's share capital (especially, of those living in the science polis zone who will be able to purchase preferred shares). Today, in general, the idea of Akademgorodok 2.0 has not yet fully captured its residents; they take a passive wait-andsee attitude towards it, at best. Having become shareholders, they will be vitally interested in its success.
}

tion should also be paid to what is possible here for the CIS and the EAEU.

In the event of setting up of the National Science and Technology Corporation for the Development of Siberia, the institutes of the Academy, NSU, technoparks, and other structures of the science polis zone may enter it based on dual subordination, while maintaining their current status. Basically, this corporation should resemble in its features a national development institution (such as the Russian Venture Company, RVC).

With the radicalization of the management model in the science polis zone, it should be assumed that the NSU's role as the system integrator of scientific developments, higher and secondary education, and interaction with industrial partners will objectively increase in the future regional scientific and technological ecosystem of the NSC. However, the science polis zone's main structural elements, primarily the SB RAS institutes and NSU, should also retain their status, and their mutual mergers or take-overs should not occur. ${ }^{18}$

\section{SPATIAL ASPECTS OF THE GOVERNANCE SYSTEM IN THE SCIENCE POLIS ZONE}

In different countries, the issues of managing regional scientific and innovative systems are resolved in different ways. A comparative analysis of these processes is presented in $[2,6]$.

Of particular interest here is the recent experience of China [4]. The technological breakthrough this country had made over the last few decades relied primarily on national-scale scientific and innovative centers. As a rule, they were concentrated in the capital cities of the provinces within special economic zones. Thus, there are several zones of regional high-tech development among 49 special economic zones at the national level in China. From this article's standpoint, we will consider the Changchun High-Tech Industrial Development Zone in the northeastern Jilin Province, which has many similar development parameters with the NSC. ${ }^{19}$ Its innovative cluster is developing in five main areas: biotechnology (including biopharmaceuticals), photonics, information technology, new materials, and automotive (production of complex parts and components of cars for automotive plants). There are 14 universities and colleges (among them Jilin University with 60000 students), and 15 nationallevel research laboratories in the Changchun Zone.

This zone has the status of a separate district of the city of Changchun and has its system of state (and

\footnotetext{
${ }^{18}$ We considered these issues in the article "Big University: where, which, why,". http://www.sbras.info/articles/opinion/bolshoiuniversitet-gde-kakoi-zachem. Accessed June 11, 2020.

${ }^{19}$ Our analysis is based on visits to this zone and conversations with its management. See: "Akademgorodok 2.0": made in China. http://www.sbras.info/articles/opinion/akademgorodok-20-made-china. Accessed May 20, 2020.
} 
party) management in the form of a special management committee that combines the functions of managing scientific, technological, and municipal development in this territory. The committee's most important functional subdivisions are the Committee for Science and Technological Innovation and the Committee for Attracting Investment. These Committees make decisions about the infrastructure development of the territory (about $50 \mathrm{~km}^{2}$ ), housing construction, medical services, attracting repatriates (ethnic Chinese working in world's high-tech companies), etc. The administration of the zone, taking advantage of the system of tax benefits and preferences granted to it as a special zone at the national level, puts in its paramount efforts to attract private investors for hightech industries.

An exceptionally comfortable living environment in the zone has shaped thanks to modern urban planning solutions, landscape design, and others. About 300000 people live and almost 8000 enterprises are registered there, including about 150 ones with foreign participation. The bulk of the enterprises are small and medium-sized high-tech businesses. A handful of large companies also operate within the zone (five with an annual production volume of over USD 0.7 billion and three with a volume of over USD 1.5 billion). It ranks sixth in terms of trade turnover among the 49 special economic zones at the national level, and is also included in the official Top 10 Chinese special economic zones based on a set of criteria.

The experience of establishing the Changchun High-Tech Industrial Development Zone, which effectively realized its competitive advantages, shows the fundamental possibility of implementing a model for the development of a regional scientific and technological system combining the management of scientific and technological development, the management of attracting investors, and the management of the comfortable development of the territory. This management model proved to be successful only due to the strong government support in the form of the status of a national-level special zone with an appropriate system of preferential taxation and preferential conditions for doing science-intensive business. It is exactly what we would like to see in the Akademgorodok 2.0 management system.

As for the issues of the territorial management of the science polis zone (Akademgorodok 2.0), there are three options we deem possible:

- the program for the development of the NSC SB RAS as a territory with a high concentration of research and development is implemented in the existing administrative and territorial structure;

- for the implementation of the program, a new urban district is created (possibly with naukograd rights), which includes the main supporting territories of the science polis zone;
- the administrative and territorial structure remains as it is with a special order of the federal center fixing the spatial area of the Akademgorodok 2.0 project with temporary boundaries for the period of its formation and with a list of particular forms for conducting scientific activities, business, and attracting institutional investors for this period. This practice was once used in the United States: the so-called "mosquito abatement districts" were set up to control mosquitoes in order to protect the population from the danger of mosquito-borne diseases.

Certainly, the prospects of the second option are very tempting, in which a single new urban district is created with its own management system, which includes both the traditional system of municipal government and the system for managing the research and development and technological development of this territory (as in the case of the Changchun Zone). For example, it would solve the problem of appointing a lead manager of budget funds for financing intermunicipal infrastructural projects. However, firstly, this option will take much more time and effort, and secondly, it would be tough to reach a sociopolitical consensus between the local authorities and the population. Therefore, as an easier option, we can consider a management model for the science polis zone based on granting this area the status of a territory of advanced scientific and technological development. Simultaneously, the existing municipalities retain their administrative and territorial status, but special intermunicipal structures are established to manage research, development, and innovation (as well as intermunicipal infrastructure projects). However, this will require serious justification for the effectiveness and feasibility of implementing such a management system and amendments to the Federal Law no. 473FZ of December 29, 2014 On the territories of advanced socioeconomic development in the Russian Federation.

\section{CONCLUSIONS}

(1) A new stage in developing the NSC as a territory with a high concentration of research and development has begun. It is being implemented in the form of the Akademgorodok 2.0 megaproject, designed to combine the efforts of academic science, higher education, and high-tech business in order to establish a world-class regional scientific and innovative system. National centers of competence in synchrotron radiation, genetic technologies, high-performance computing, MegaScience class facilities, and supercomputer centers are being created here. Novosibirsk's science and innovation achievements have become recognized leaders in creating the global industry of single-walled carbon nanotubes, and these developments were awarded the State Prize of the Russian Federation in 2020. The NSC's scientific and innovative complex has confirmed its high key competencies 
in the fight against coronavirus. Combining the efforts of the State Scientific Center of Virology and Biotechnology "Vector," the SB RAS institutes, NSU, and other innovative companies have led to the creation of several variants of vaccines, test systems, means of protection against coronavirus, etc. The interagency working group on coronavirus infection set up at the NSC SB RAS has shown itself to be an effective model for the interaction of science, higher education, and innovative companies in the fight against this global threat.

(2) An essential feature of the new stage of the NSC's development was the significant strengthening of the integrational interaction between academic institutions, NSU, the Technopark of the Novosibirsk Akademgorodok and its residents, and other innovative companies. In these interactions, NSU's role as the systems integrator for research and development began to increase. At the same time, the spatial expansion of the NSC is taking place: it includes the neighboring territories of naukograd Koltsovo, the city of Berdsk, and the urban-type settlement Krasnoobsk. It is required to choose a new spatial model for the development of the Novosibirsk territory of the science polis zone, effective urban planning solutions, and its management system. As a result, Akademgorodok 2.0 has become the model example of the integration between regional and urban strategic planning and management, territorial planning (including urban planning and infrastructure design), and the planning and management of scientific and technological development.

(3) The tendencies mentioned above suggest that one of the first Russian regional scientific and innovation ecosystems is being formed in the NSC zone. It is interpreted as a self-organizing, self-regulating, and self-developing open system characterized by the input flows of ideas, value, people, information, and resources in regional scientific and innovative development. The foreign experience in developing regional innovation ecosystems is described in [19, 20]. We share the position expressed by L.G. Karanatova and A.Yu. Kulev, who believe that "the regional innovation ecosystem is the most developed element of the national innovation ecosystem since the territory is both a consumer and a customer of innovative products, services, and innovations aimed, among other things, at creating comfortable conditions for achieving competitiveness by the territories in the problems of ensuring the innovative development at the meso-level-the competence of human capital" [3, p. 41]. All this applies fully to Akademgorodok 2.0.

(4) The analysis shows that in the context of the crisis in the global and Russian economies related to the coronavirus pandemic and the sharp drop in oil prices, and the widespread decline in demand, investment, and production, the development of Akademgorodok 2.0 should be carried out according to the inertial scenario. It starts here with a limited range of projects to establish scientific, educational, and innovative infrastructures and individual objects of the social, transport, and engineering infrastructure. The most significant progress is related to the start of works on the Siberian ring photon source (SRPS or SKIF). Not only is it a multibillion-dollar project of the MegaScience class but one that creates new, highly productive jobs and new objects of the engineering, social, and transport infrastructure. The difficulties with its launch confirm the need for establishing an effective management system for the development of Akademgorodok 2.0 that unifies the economic, scientific and technological, institutional, legal, and urban planning factors and conditions.

\section{FUNDING}

The article was prepared as part of the research plan of the IEIE SB RAS, project no. XI.173.1.1 "Project/program approach in state regional policy and regional strategic planning and management: methodology, practice, institutions."

\section{CONFLICT OF INTEREST}

The author declares that he has no conflict of interest.

\section{REFERENCES}

1. Dezhina, I., Development institutions: What is known about their effectiveness? Troitskii Variant, 2013. https://trv-science.ru/2013/04/09/instituty-razvitiyachto-izvestno-ob-ikh-ehffektivnosti/. Accessed July 2, 2019.

2. Ivanov, V.V., Innovatsionnaya paradigma XXI (Innovative Paradigm 21st), Moscow: Nauka, 2015, 2nd ed.

3. Karanatova, L.G. and Kulev, A.Yu., Modern approaches to the formation of ecosystems in the conditions of the development of the knowledge economy, Upr. Konsult., 2015, no. 12, pp. 39-46.

4. Klyuchikhin, E.A., Scientific and innovative policy of China, Mezhdunar. Protsessy, 2013, no. 2 (33), pp. 3755.

5. Kravchenko, N.A. and Markova, V.D., Multi-agent interactions in the regional innovation system, Innovatsii, 2018 , no. 6 , pp. $51-55$.

6. Kul'kin, A.M., Nauchnye i tekhnologicheskie parki, tekhnopolisy i regiony nauki (Scientific and Technological Parks, Technopolises, and Regions of Science), Moscow: Inst. Nauchn. Inf. Obshch. Naukam, 2005.

7. Markova, V.D., Development of engineering infrastructure in the scientific-innovative sphere (case study of the Novosibirsk oblast), Innovatsii, 2019, no. 3, pp. $51-55$.

8. Benneworth, P., Pinheiro, R. and Karlsen, J., Strategic agency and institutional change: investigating the role of universities in regional innovation systems (RISs), Reg. Stud., 2017, vol. 52, no. 2, pp. 235-248. 
9. Cooke, P., Regional innovation systems: an evolutionary approach, in Regional Innovation Systems: The Role of Governance in a Globalised World, Cooke, P., Heidenreich, M., and Braczyk, H.-J., Eds., London: Routledge, 2004, pp. 1-18.

10. Cooke, P., Regional innovation systems, clusters, and the knowledge economy, Ind. Corp. Change, 2001, vol. 10, no. 4, pp. 945-974.

11. Koukoufikis, G., The incorporation of EU's Innovation policy in its regions. Insights from Basse-Normandie and Thessaly, PhD Thesis, Tours: Univ. Francois-Rabelais, 2014. https://www.academia.edu/8387357/The_incorporation_of_EUs_Innovation_policy_in_its_regions_Insights_from_Basse-Normandie_and_Thessaly, 2014.

12. Lundvall, B.-A., National Systems of Innovation: Toward a Theory of Innovation and Interactive Learning, London: Pinter, 1992.

13. Martin, R., Wiig Aslesen, H., Grillitsch, M., and Herstad, S., Regional innovation systems and global flows of knowledge. https://www.researchgate.net/publication/316586381_Regional_innovation_systems_and_g lobal_knowledge_flows.

14. Morisson, A. and Doussineau, M., Regional innovation governance and place-based policies: design, implementation and implications, Reg. Stud., Reg. Sci., 2019, vol. 6, no. 1, pp. 101-116. https://rsa.tandfonline.com/doi/full/10.1080/21681376.2019.1578257
15. National Innovation Systems: A Comparative Analysis, Nelson, R., Ed., Oxford: Oxford Univ. Press, 1993.

16. Power, D. and Malmberg, A., The contribution of universities to innovation and economic development: in what sense a regional problem? Cambridge J. Reg., Econ. Soc., 2008, vol. 1, pp. 233-245.

17. Reichert, S., The Role of universities in regional innovation ecosystems, European University Association, 2019. https://eua.eu/downloads/publications/eua\%2 0innovation\%20ecosystem\%20report\%202019v1.1_final_digital.pdf.

18. Seliverstov, V.E., Akademgorodok 2.0 megaproject: Are dreams coming true? Reg. Res. Russ., 2020, vol. 10, no. 1 , pp. 107-116. https://doi.org/10.1134/S2079970520010098

19. Spencer, G.M., Regional Innovation Ecosystems. Key Factors of Technological Innovation and Entrepreneurship: A Report, Toronto: Ontario Minist. Res. Innovation Sci., 2013. https://localideas.files.wordpress.com/ 2014/05/regional-innovation-ecosystems.pdf.

20. Wessner, C.W., Entrepreneurship and the innovation ecosystem. Policy lessons from the United States, in Local Heroes in the Global Village: Globalization and the New Entrepreneurship Policies, New York: SpringerVerlag, 2004, pp. 67-89.

Translated by I. Pertsovskaya 